\title{
Medusae, siphonophores and ctenophores of the Magellan region*
}

\author{
FRANCESC PAGÈS ${ }^{1}$ and COVADONGA OREJAS ${ }^{2}$ \\ ${ }^{1}$ Institut de Ciències del Mar, Plaça del Mar s/n, 08039 Barcelona, Spain \\ ${ }^{2}$ Alfred-Wegener-Institut für Polar- und Meeresforschung, Columbusstraße, 27568 Bremerhaven, Germany
}

\begin{abstract}
SUMMARY: Medusae, siphonophores and ctenophores were conspicuous and relatively abundant organisms in the Magellan Straits, Beagle Channel and adjacent waters during the "Victor Hensen" campaign in 1994. Hydromedusae were the most abundant component of this assemblage (mainly Bougainvillia macloviana, Clytia simplex and Obelia spp.) and showed the highest number of species (29). Siphonophores were second in species number (8) and mainly occurred outside the Magellan Straits (mainly Muggiaea atlantica, Dimophyes arctica, Lensia conoidea and Pyrostephos vanhoeffeni). Callianira antarctica was the only mesozooplanktonic ctenophore and showed a widespread distribution throughout the region. Aggregations of large Beroe cucumis and Desmonema gaudichaudi were observed at some stations. The abundance and depth distribution is given for the most important species and some patterns in the species distribution are postulated.
\end{abstract}

Key words: Medusae, siphonophores, ctenophores, Magellan Straits, Beagle Channel.

RESUMEN: MEdUSAS, SIFONÓForos y CTENÓFOROS EN LA REgión MAGALLÁNICA. - Medusas, sifonóforos y ctenóforos fueron organismos notorios y relativamente abundantes en el Estrecho de Magallanes, Canal del Beagle y aguas circundantes durante la campaña del "Victor Hensen" en 1994. Las hidromedusas constituyeron el componente más abundante de este conjunto (principalmente Bougainvillia macloviana, Clytia simplex y Obelia spp.) y mostraron el mayor número de especies (29). Los sifonóforos fueron el segundo grupo en número de especies (8) y se distribuyeron principalmente fuera del Estrecho de Magallanes (principalmente Muggiaea atlantica, Dimophyes arctica, Lensia conoidea y Pyrostephos vanhoeffeni). Callianira antarctica fué el único ctenóforo mesozooplanctónico y mostró una amplia distribución en toda la región. Agregaciones de ejemplares grandes de Beroe cucumis y Desmonema gaudichaudi fueron observadas en algunas estaciones. Se presenta la abundancia y distribución batimétrica para las especies más importantes y se postulan algunas pautas de distribución.

Palabras clave: Medusas, sifonóforos, ctenóforos, Estrecho de Magallanes, Canal del Beagle.

\section{INTRODUCTION}

The geographical position of the Magellan Region, the main Subantarctic land between $50^{\circ}$ and $60^{\circ} \mathrm{S}$, characterized by fjords, channels and islands,

This is AWI contr. no. 1752

*Accepted October 15, 1998. and limited by the Pacific, Atlantic and Southern Oceans invites investigation of the composition and distribution of the planktonic fauna for zoogeographical studies. Our knowledge about the plankton populations of this region has increased substantially thanks to the recent publication of the Atlas of the Marine Zooplankton - Straits of Magellan (Mazzochi et al., 1995; Guglielmo and Ianora, 1997) 
dealing with copepods, amphipods, euphausiids, mysids, ostracods and chaetognaths. However, a significant assemblage of organisms -the gelatinous zooplankton- was regrettably omitted.

In Antarctic and Subantarctic waters, the current knowledge about the species composition and distribution of the filter-feeder gelatinous zooplankton (salps, doliolids, appendicularians and pyrosomes) is quite acceptable. On the contrary, that on gelatinous carnivores is widely biased between regions and faunistic groups (Pagès, 1997); the Atlantic sector has been investigated more intensely and the medusae fauna is better known than the siphonophores, and knowledge of the latter is more complete than that of the ctenophores. A circumpolar distribution for most species is accepted in spite of theses gaps. Latitudinally, most of the bathy- and mesopelagic species follow a continuous distribution in Antarctic and Subantarctic waters (Kramp, 1959); but this statement is less clear for epipelagic species due to the influence of the Polar Front.

Surprisingly, much less information is available from Subantarctic waters in comparison with Antarctic ones. One of the main gaps concerns the gelatinous zooplankton inhabiting the Magellan region (Fig. 1). The sparse data published were obtained after some accidental or sporadic sampling (e.g. Chun, 1898). Kramp (1959) emphasized that the Polar Front constitutes a rather distinct barrier between the Antarctic and Subantarctic faunas in the south-western Atlantic.

The study of the gelatinous zooplankton was one of the objectives of the Magellan "Victor Hensen" Campaign in 1994. The examination of the plankton samples collected has indicated that the filter-feeding gelatinous zooplankton was very scarce during the sampling period (Antezana et al., 1996) but medusae, siphonophores and ctenophores were abundant. The present paper is the most comprehensive study to date on the taxonomic composition and spatial distribution of the gelatinous carnivores in this region.

\section{MATERIAL AND METHODS}

In the Straits of Magellan (leg 1) zooplankton samples were collected by oblique hauls in the 50-0 $\mathrm{m}$ depth range with a Bongo net $(60 \mathrm{~cm}$ mouth
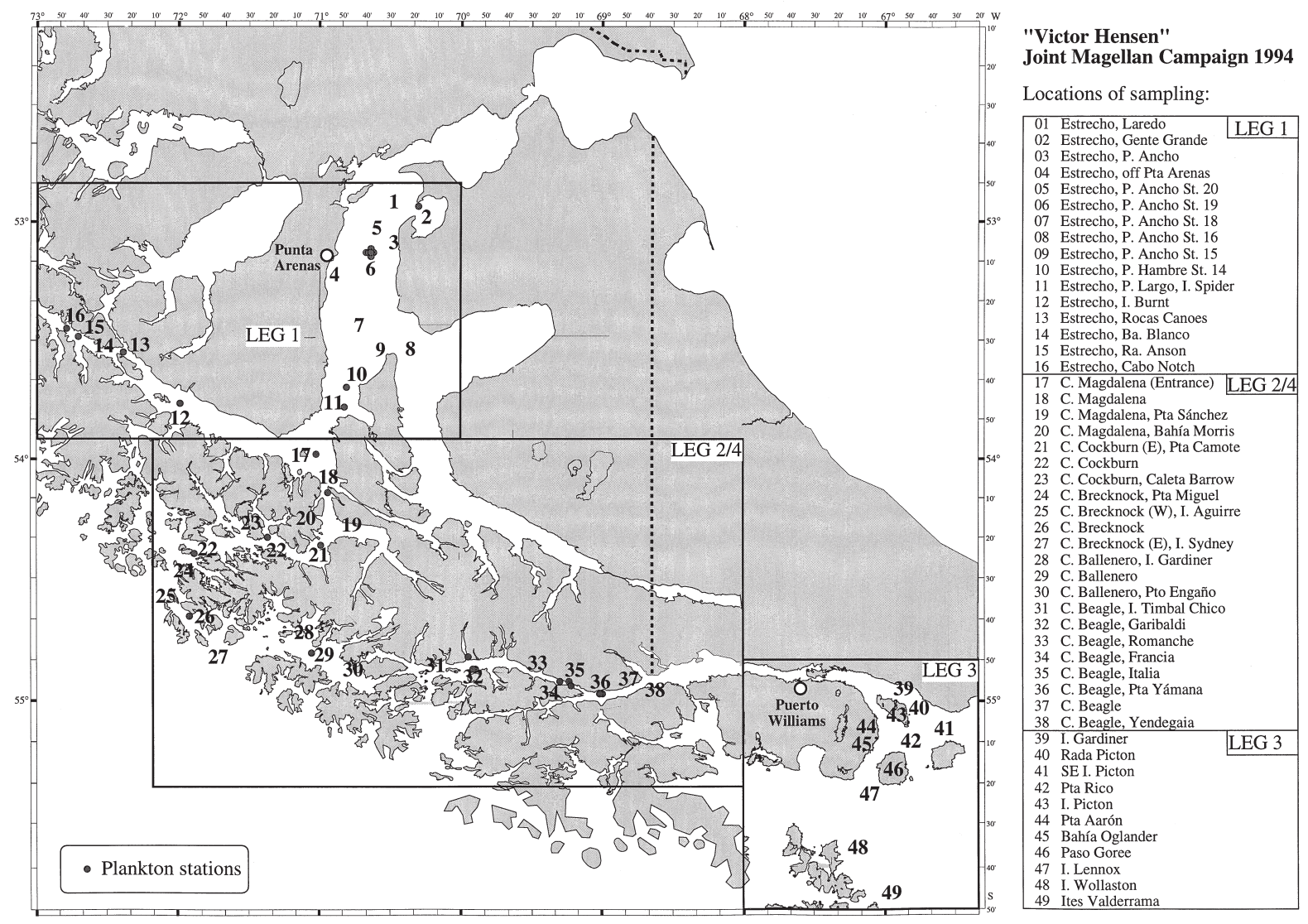

FIG. 1. - Locations of plankton sampling stations during the Joint Magellan Campaign. 
TABLE 1. - Presence (+) or absence (-) of the species collected in the "Victor Hensen" cruise in six main latitudinal regions and ordered from Antarctic to the Arctic. * indicates a single occurrence.

\begin{tabular}{|c|c|c|c|c|c|c|}
\hline & Antarctic & Subantarctic & $\begin{array}{c}\text { Temperate waters } \\
\text { of southern } \\
\text { hemisphere }\end{array}$ & $\begin{array}{l}\text { Temperate waters } \\
\text { of northern } \\
\text { hemisphere }\end{array}$ & Boreal & Arctic \\
\hline Laodicea pulchra & $*$ & + & - & - & - & - \\
\hline Margelopsis australis & + & + & - & - & - & - \\
\hline Desmonema gaudichaudi & + & + & - & - & - & - \\
\hline Pyrostephos vanhoeffeni & + & + & $*$ & - & - & - \\
\hline Callianira antarctica & + & + & $*$ & - & - & - \\
\hline Mitrocomella frigida & + & + & $*$ & - & - & - \\
\hline Cosmetirella davisi & + & + & + & * & - & - \\
\hline Solmundella bitentaculata & + & + & + & + & + & - \\
\hline Dimophyes arctica & + & + & + & + & + & + \\
\hline Beroe cucumis & + & + & + & + & + & + \\
\hline Halopsis ocellata & + & + & - & - & + & + \\
\hline Hybocodon sp. & - & + & - & - & - & - \\
\hline Linvillea sp. & - & + & - & - & - & - \\
\hline Bougainvillia sp. & - & + & - & - & - & - \\
\hline Calycopsis sp. & - & + & - & - & - & - \\
\hline Cunina sp. & - & + & - & - & - & - \\
\hline Rathkea formossisima & - & + & $*$ & - & - & - \\
\hline Proboscidactyla mutabilis & - & + & $*$ & - & - & - \\
\hline Amphogona apicata & - & + & + & + & - & - \\
\hline Rhabdoon singulare & - & + & + & + & - & - \\
\hline Aequorea macrodactyla & - & + & + & + & - & - \\
\hline Amphinema rugosum & - & + & + & + & - & - \\
\hline Leuckartiara octona & - & + & + & + & - & - \\
\hline Podocoryne minuta & - & + & + & + & - & - \\
\hline Clytia simplex & - & + & + & + & - & - \\
\hline Bougainvillia macloviana & - & + & + & + & - & - \\
\hline Sphaeronectes gracilis & - & + & + & + & - & - \\
\hline Sphaeronectes fragilis & - & + & + & + & - & - \\
\hline Euphysa aurata & - & + & + & + & + & - \\
\hline Heterotiara anonyma & - & + & + & + & + & - \\
\hline Colobonema sericeum & - & + & + & + & + & - \\
\hline Obelia spp. & - & + & + & + & + & - \\
\hline Modeeria rotunda & - & + & + & + & + & - \\
\hline Rhopalonema velatum & - & + & + & + & + & - \\
\hline Aurelia aurita & - & + & + & + & + & - \\
\hline Lensia conoidea & - & + & + & + & + & - \\
\hline Muggiaea atlantica & - & + & + & + & + & - \\
\hline Eudoxoides spiralis & - & + & + & + & + & - \\
\hline Sphaeronectes irregularis & - & + & - & + & - & - \\
\hline Mitrocomella polydiademata & - & + & - & + & + & - \\
\hline Podocoryne borealis & - & + & - & - & + & - \\
\hline
\end{tabular}

diameter, $300 \mu \mathrm{m}$ mesh-size) during day and night. The gelatinous zooplankton contained in 16 of the 31 Bongo samples was sorted on board $R / V$ "Victor Hensen" for a posterior examination at the AlfredWegener-Institut. Samples were not collected quantitatively in this area and only the occurrence of the species is reported.

In the Beagle Channel and adjacent waters (legs 3 and 4), a multiple opening/closing net system $\left(0.25 \mathrm{~m}^{2}, 300 \mu \mathrm{m}\right.$ mesh-size $)$ was hauled vertically at 23 stations. Daytime hauls were conducted depending on the bathymetry, covering standard depth intervals of 0-10-20-30-50-100 $\mathrm{m}$ for the shallow casts, and 0-100-150-200-300-400 for the deep hauls. The samples were fixed in $4 \%$ borax buffered formalin. The volume of water filtered was calculated from the vertical distance $(\mathrm{m})$ covered by the net's mouth area assuming a $100 \%$ efficiency. The medusae, siphonophores (both sexual and asexual stages) and ctenophores were identified according to the present knowledge of the systematics of both groups. All specimens were counted and the counts standardized to number of specimens per $100 \mathrm{~m}^{3}$.

\section{RESULTS AND DISCUSSION}

At least 41 species of gelatinous carnivores have been identified from the Bongo and Multinet samples, namely 29 hydromedusae, 8 siphonophores, 2 scyphomedusae and 2 ctenophores (Table 1). Among them 5 hydromedusae species, all occurring occasionally, could only be identified to genus level because they do not fit with any known species. 
Mean abundances of gelatinous carnivores along the water column varied from $66.7 \pm 23$ specimens per $100 \mathrm{~m}^{3}$ off Barnevelt Island (20-0 m depth) to $387 \pm$ 151 specimens per $100 \mathrm{~m}^{3}$ off Romanche Glacier, Beagle Channel (30-0 m depth). In the Magellan Straits, hydromedusae dominated the populations of gelatinous mesozooplankton, and the scyphomedusa Desmonema gaudichaudi was the most conspicuous macroplanktonic organism. Siphonophores, ctenophores and salps were rarely collected. On the contrary, south of the Magellan Straits, siphonophores and ctenophores were as abundant as hydromedusae, whereas scyphomedusae were not collected. These differences are partly caused by the sampling methods used in each area.

In all the sampling area the anthomedusan Bougainvillia macloviana Lesson and the leptomedusae Clytia simplex Browne and Obelia spp. were the most abundant hydroidomedusae in the top 50 meters. Bougainvillia macloviana was by far the most abundant species in the Magellan Straits and was collected at almost all stations, principally in Paso Ancho. Its abundance decreased in the Pacific branch, being absent in Cabo Notch, the closest station to the western mouth of the Magellan Straits. A few specimens were found in the Magdalena and Cockburn channels and also in the eastern mouth of the Beagle Channel. Likewise several young and adult individuals of another unidentified species of Bougainvillia were collected betrween the Magellan Straits and the mid part of the Beagle Channel.

Clytia simplex was widely distributed from the Magellan Straits to the eastern mouth of the Beagle Channel, mainly in the 50-0 m depth range although a deeper distribution was shown in the Cockburn Channel $(300-0 \mathrm{~m})$ where it reached the highest abundance $\left(440\right.$ specimens per $\left.100 \mathrm{~m}^{3}\right)$ in the $30-20$ $\mathrm{m}$ depth range. This species was originally described from the Falkland Islands and has been recorded in South Africa, Australia, Brazil and more recently in the Mexican Caribbean $\left(20-21^{\circ} \mathrm{N}\right)$ (Segura-Puertas, 1992).

Obelia spp. had a widespread distribution in the region but it mainly occurred in the top $100 \mathrm{~m}$ between Ballenero Channel and the stations located on the eastern mouth of the Beagle Channel. Maximum densities were found in Punta Yámana (360 specimens per $100 \mathrm{~m}^{3}$ in the $30-20 \mathrm{~m}$ depth range). These medusae are possible $O$. geniculata (Linneaus, 1758) or $O$. bidentata Clarke, 1875 , the Obelia hydroids identified from the benthos samples, but they were only found in Gente Grande and
Paso Ancho (Orejas, unpublished data) pointing out an apparent uncoupling between the distribution of the pelagic and benthic stages.

Cosmetirella davisi (Browne) was collected in the Magellan Straits, Magdalena, Brecknock and Ballenero channels, and in the eastern mouth of the Beagle Channel mainly in the top $100 \mathrm{~m}$ depth. Maximum numbers (200 specimens per $100 \mathrm{~m}^{3}$ ) were observed in Isla Aguirre in the 20-10 m depth range. It occurs principally in Antarctic and Subantarctic waters although it has also been recorded in South Africa (Kramp 1959).

Mitrocomella frigida (Browne) was found in the Magellan Straits, Magdalena, Cockburn, Brecknock channels and the eastern mouth of the Beagle Channel at discrete depth ranges between 300 and $10 \mathrm{~m}$ depth. The highest abundance (112 specimens per $100 \mathrm{~m}^{3}$ ) was reached in Cockburn Channel in the 200-150 m depth range. It occurs principally in Antarctic and Subantarctic waters and has also been recorded in South Africa (Kramp 1959).

The limnomedusan Proboscidactyla mutabilis (Browne) was always found in low densities (up to 80 specimens per $100 \mathrm{~m}^{3}$ ) but widely distributed in the region except the Pacific branch of the Magellan Straits. This species showed a widespread depth distribution outside the Magellan Straits occurring in all depth intervals except the 10-0 depth range. It was originally described from specimens collected in the Falkland Islands and has also been found in the Straits of Magellan, the Patagonian Bank and near the coast of southern Patagonia (Kramp, 1959). Fagetti (1973) thinks that she found two specimens in Valparaíso Bay.

The bipolar leptomedusan Halopsis ocellata Agassiz occurred in very low densities (up to 40 specimens per $100 \mathrm{~m}^{3}$ ). This species showed a scattered distribution in the Magellan Straits, Magdalena, Cockburn and Brecknock channels in the 300-30 $\mathrm{m}$ depth range. It was also collected in the eastern mouth of the Beagle Channel in the 100-20 m depth range.

The anthomedusan Podocoryne borealis Mayer was collected in Canal Ballenero and the mid part of the Beagle Channel between $50 \mathrm{~m}$ depth and the surface. Its abundance was low and reached 160 specimens per $100 \mathrm{~m}^{3}$ in the $10-0 \mathrm{~m}$ depth range in Canal Ballenero. This species is recorded for the first time in the southern hemisphere. Our specimens match with the description given by Edwards (1972) for the specimens that he reared to maturity from the hydroid collected in the Clyde Sea. Its geographical 
distribution was previously restricted to the North Atlantic east and west basins. Edwards (1972) mentioned that this species is boreal and is not known to occur in the Subarctic.

The leptomedusan Laodicea pulchra Browne was collected in Magdalena (200-50 m depth range) and Cockburn (200-150 m depth range) channels, Isla Aguirre (300-50 m depth range), Glaciar Francia (150-10 m depth range) and in the eastern mouth of the Beagle Channel in the 100-50 and 10-0 m depth ranges respectively. Densities were low and reached maximum numbers in Isla Aguirre (up to 48 specimens per $100 \mathrm{~m}^{3}$ ) in the $100-50 \mathrm{~m}$ depth range. This species was previously found in the vicinity of the Falkland Islands, between these islands and the coast of Patagonia (Kramp 1959) and in the Ross Sea (Foster 1989).

The trachymedusan Amphogona apicata Kramp was the most abundant species in the $400-100 \mathrm{~m}$ depth range. Its distribution was mainly restricted to the Beagle Channel between Isla Timbal Chico and Glaciar Francia in the 400-50 m depth range. The peak of the population (344 specimens per 100 $\mathrm{m}^{3}$ ) was found at the Glaciar Francia in the 200$150 \mathrm{~m}$ depth range. This is an uncommon deepwater species recorded in the southern hemisphere near the Falkland Islands and South Georgia, near the Cape of Good Hope, in the Moçambique Channel (Kramp, 1957) and near the east coast of New Zealand (Kramp, 1965). In the northern hemisphere it has been found in Atlantic waters between $29^{\circ} 59^{\prime}$ and $45^{\circ} 02^{\prime} \mathrm{N}$ (Bleeker and van der Spoel, 1988).

The anthomedusan Margelopsis australis Browne was collected only in the Beagle Channel between Isla Timbal Chico and Glaciar Francia (400-100 m depth range) in very low densities (up to 24 specimens per $100 \mathrm{~m}^{3}$ ). This is a rare species only recorded in the Gauss station, McMurdo Sound and between South Georgia and Bouvet Island (Kramp, 1959).

Another rare anthomedusan, Rathkea formossisi$m a$ (Browne) was found in Romanche, Beagle Channel (50-30 m depth) and in its eastern mouth (10-0 m depth) in low densities (up to 40 specimens per $100 \mathrm{~m}^{3}$ ). This species was originally described from the Falkland Islands and recently was recorded for New Zealand (Schuchert, 1996).

Muggiaea atlantica Cunningham was the most abundant siphonophore and mainly occurred in Magdalena, Cockburn and Brecknock channels. Polygastric stages and eudoxids of this neritic species were found along the whole water column but the latter were more abundant in most depth ranges peaking in Isla Aguirre between 200 and 150 $\mathrm{m}$ depth (336 eudoxids per $100 \mathrm{~m}^{3}$ ). It was the only siphonophore collected in the Magellan Straits.

The cosmopolitan calycophore Dimophyes arctica (Chun) was the second most abundant siphonophore and mostly occurred in the central part of the Beagle Channel, between Isla Timbal Chico and Glaciar Francia, in the 400-50 m depth range. Eudoxids were more abundant than polygastric stages and reached maximum numbers (336 eudoxids per $100 \mathrm{~m}^{3}$ ) in Isla Timbal Chico (150-100 m depth) and Glaciar Francia (100-50 m depth), respectively.

Lensia conoidea (Keferstein and Ehlers) was third in the rank and mainly occurred in Ballenero Channel and the western mouth of the Beagle Channel, between 400 and 50 m depth. Maximum abundance was found in the 100-50 $\mathrm{m}$ depth range (376 eudoxids per $100 \mathrm{~m}^{3}$ ).

Some colonies of the Antarctic physonect Pyrostephos vanhoeffeni Moser were found scattered in Magdalena, Cockburn, Brecknock and Ballenero channels between 400 and $50 \mathrm{~m}$ depth. They were also collected in the eastern mouth of the Beagle Channel (100-20 m depth range) but not in the Beagle Channel and the Magellan Straits. This species though not abundant, is widely distributed in the Southern Ocean (Pagès et al., 1994; Pagès and Schnack-Schiel, 1996) and Subantarctic waters. An accidental occurrence was recorded in Valparaíso waters $\left(33^{\circ} \mathrm{S}\right)$ by Palma (1986).

Callianira antarctica Chun was the only ctenophore identified in the Multinet samples. It was found in the Magellan Straits, Magadalena, Cockburn, Brecknock and Ballenero channels at all depth ranges between 400 and $30 \mathrm{~m}$. It also occurred in the mid part of the Beagle Channel between 100 and 30 $\mathrm{m}$ depth and was never collected in the top $30 \mathrm{~m}$ depth in this broad area. However, it was collected at all depth intervals between $100 \mathrm{~m}$ and the surface in the eastern mouth of the Beagle Channel. The maximum abundance was recorded off Isla Aguirre (544 specimens per $100 \mathrm{~m}^{3}$ ) in the $150-100 \mathrm{~m}$ depth range. The preserved specimens have been identified from the description and figure given by Chun (1898) from specimens collected in the Magellan Straits and Churruca Bay. Moser (1909) reported its occurrence in the Gauss Station (Antarctica), Kerguelen Islands and at $31^{\circ} \mathrm{S}$ on the Atlantic coast of South Africa. 
The examination of the distribution of the most significant species suggests four main distribution patterns in the Magellan region:

1.- Species occurring in all the Magellan region from the Straits of Magellan until the eastern mouth of the Beagle Channel: Clytia simplex, Proboscidactyla mutabilis and Callianira antarctica.

2.- Species occurring in the Magellan region with the exception of the Beagle Channel: Bougainvillia macloviana, Cosmetirella davisi, Mitrocomella frigida, Halopsis ocellata, Laodicea pulchra and Muggiaea atlantica.

3.- Species occurring from Ballenero Channel to the eastern mouth of the Beagle Channel: Obelia spp. and Rathkea formossisima.

4.- Species distributed only between the Ballenero and Beagle channels: Podocoryne borealis, Amphogona apicata, Margelopsis australis, Dimophyes arctica and Lensia conoidea.

A comparison with the fauna of the Falkland Islands is only possible for the hydroidomedusae. Browne and Kramp (1939) reported 17 species. If we exclude Obelia spp., six of them have been collected during the "Victor Hensen" cruise: Bougainvillia macloviana, Rathkea formossisima, Laodicea pulchra, Cosmetirella davisi, Clytia simplex and Proboscidactyla mutabilis.

Table 1 shows the latitudinal distribution of the 41 species collected during the "Victor Hensen" cruise. Aside from five (12.5\% of the total) species (Hybocodon sp., Linvillea sp., Bougainvillia sp., Calycopsis sp., and Cunina sp.) that are probably new to science (for which a taxonomic study is currently being carried out), no species shows a strict Subantarctic distribution. Six species (Laodicea pulchra, Margelopsis australis, Pyrostephos vanhoeffeni, Callianira antarctica, Mitrocomella frigida and Desmonema gaudichaudi) also occur in Antarctic waters. Rathkea formossisima and Proboscidactyla mutabilis are Subantarctic species that seem to extend their distribution to temperate waters of the southern hemisphere. Eight species (20.0\%), Rhabdoon singulare, Aequorea macrodactyla, Amphinema rugosum, Leuckartiara octona, Podocoryne minuta, Clytia simplex and Bougainvillia macloviana extend to temperate waters of the northern hemisphere. At least ten species (25\%), Euphysa aurata, Heterotiara anonyma, Colobonema sericeum, Obelia spp., Modeeria rotunda, Rhopalonema velatum, Aurelia aurita, Lensia conoidea, Muggiaea atlantica and Eudoxoides spiralis are wide- ly distributed between boreal and Subantarctic waters. Two, Dimophyes arctica and Beroe cucumis, are cosmopolitan and two more, Halopsis ocellata and Podocoryne borealis, are bipolar. The rest of the species show erratic distribution patterns probably because of biased sampling.

After the present paper was reviewed and in press we noticed the publication of a study on the siphonophores from southern Chilean inlets between $41^{\circ} 30^{\prime}$ and $46^{\circ} 40^{\prime} \mathrm{S}$ (Palma and Rosales, 1997). They found 11 species including all those reported in the present study except Sphaeronectes irregularis. Note that with the exception of Dimophyes arctica, the most abundant species were the same in both areas, namely Muggiaea atlantica, Lensia conoidea and Pyrostephos vanhoeffeni.

\section{CONCLUSIONS}

The gelatinous carnivores were a conspicuous and relatively abundant group of organisms in the waters of the Magellan Region during the "Victor Hensen" campaign in 1994. Hydromedusae were the most abundant component of this assemblage and also showed the highest number of species (29). Siphonophores were the second group in species number (8) and mainly occur outside the Magellan Straits. Callianira antarctica was the only mesozooplanktonic ctenophore and showed a widespread distribution in all the region. Aggregations of large specimens of Beroe cucumis and Desmonema gaudichaudi were observed at some stations although an estimation of the abundance and biomass reached by these species requires future investigations. Some patterns in the distribution of species have been postulated but further sampling is necessary to support the trends observed and especially for establishing relationships with the hydrography. The Magellan Region seems to support a relatively high number of endemic and Subantarctic hydromedusae species. More investigations are necessary for complementing the present set of results on the gelatinous zooplankton inhabiting this important but little known biogeographical region.

\section{ACKNOWLEDGEMENTS}

We thank Claudio Richter for all the facilities given for the examination of the Multinet samples. 


\section{REFERENCES}

Antezana, T., M. Hamamé, Y. Eissler and S. Jara. - 1996. Traits of phyto- and zooplankton from the Strait of Magellan to Beagle Channel on board RV "Victor Hensen" leg 1 and 2, Oct-Nov 1994. Ber. Polarforsch., 190: 23-31.

Bleeker, J. and S. van der Spoel. - 1988. Medusae of the Amsterdam Mid North Atlantic Plankton Expeditions (1980-1983) with descriptions of two new species. Bijd. Dierk., 58: 227-258.

Browne, E.T. and P.L. Kramp. - 1939. Hydromedusae from the Falkland Islands. Discovery Rep., 18: 65-322.

Chun, C. - 1898. Die Ctenophoren der Plankton-Expedition. Ergebnisse der Plankton-Expedition der Humboldt-Stiftung. 2 K.a.: 1-32.

Edwards, C. - 1972. The hydroids and the medusa Podocoryne areolata, P. borealis and P. carnea. J. mar biol. Ass. U.K., 52 : 97-144.

Fagetti, E. - 1973. Medusas de aguas chilenas. Rev. Biol. Mar., 15: 31-75

Foster, B. - 1989. Time and depth comparisons of sub-ice zooplankton in McMurdo Sound, Antarctica. Polar Biol., 9: 431-435.

Guglielmo, L. and A. Ianora. -1997. Atlas of Marine Zooplankton. Straits of Magellan: Amphipods, Euphausiids, Mysids, Otracods and Caetognaths. Springer-Verlag, New York.

Kramp, P.L. - 1957. Hydromedusae from the Discovery collections. Discovery Rep., 29: 1-128.

Kramp, P.L. - 1959. The Hydromedusae of the Atlantic Ocean and adjacent waters. Dana Rep., 46: 1-283.
Kramp, P.L. - 1965. The Hydromedusae of the Pacific and Indian Oceans (I). Dana Rep., 63: 1-162.

Mazzocchi, M.G., G. Zagami, A. Ianora, 1. Guglielmo, N. Crescenti and J. Hure. - 1995. Atlas of Marine Zoplankton. Straits of Magellan: Copepods. Springer-Verlag, New York.

Moser, F. -1909. Die Ctenophoren der Deutschen Sudpolar-Expedition 1901-1903. Deutsche Süpolar-Expedition, 11: 1-192.

Pagès, F. - 1997. The gelatinous zooplankton in the pelagic system of the Southern Ocean: a review. Ann. Inst. océanogr. Paris, 73: $139-158$.

Pagès, F., P.R. Pugh and J-M. Gili - 1994. Macro-and megaplanktonic cnidarians collected in the eastern part of the Weddell Gyre during summer 1979. J. mar biol. Ass. U.K., 74: 873-894.

Pagès, F. and S. Schnack-Schiel - 1996. Distribution patterns of the mesozooplankton, principally siphonophores and medusae, in the vicinity of the Antarctic Slope Front (eastern Weddell Sea). J. Mar. Syst., 9: 231-248.

Palma, S. - 1986. Sifonóforos fisonectes colectados frente a Punta Curaumilla, Valparaíso. Invest. Mar., Valparaíso, 14: 69-78.

Palma, S. and S. Rosales. - 1997 (1999). Sifonóforos epipelágicos de los canales australes chilenos (41 $30^{\prime}$ - $\left.46^{\circ} 40^{\prime} \mathrm{S}\right)$. Cienc. Tecnol. Mar., 20: 125-145.

Schuchert, P. - 1996. The marine fauna of New Zealand: athecate hydroids and their medusae (Cnidaria: Hydrozoa). N. Z. Ocean. Inst. Mem., 106: 1-159.

Segura-Puertas, L. - 1992. Medusae (Cnidaria) from the Yucatán shelf and Mexican Caribbean. Bull. Mar. Sci., 51: 353-359. 